\title{
Percutaneous Tibial Length Measurement for Estimation and Correlation of Stature in Nepalese Males
}

\author{
Poudel $A^{1}$, Satyal $B^{1}$
}

\begin{abstract}
Introduction: Estimation of stature is an important step in identification of an individual, which often is required in medio-legal practice. It provides a valuable indicator for unknown individual in a population. Through the remains of human skeletal or body parts stature of an individual can be estimated. Methods and Materials: Percutaneous tibial length (PCTL) is measured in present study to estimate the stature by formulating simple regression equation. The PCTL was measured by the surface anatomical landmarks that is between most prominent part of medial condyle of tibia and tip of medial malleolus. Result: Positive correlation was found between the length of tibia and estimated height. A linear regression formula was derived for estimation of height from the length of right and left tibia. Conclusion: Estimated height and observed height were closely related within the range of error. Differences in length of right and left tibia showed statistically non-significant.
\end{abstract}

Key words: Medial condyle, medial malleolus, percutaneous tibiail length, regression formula, stature, forensic anthropology

\section{INTRODUCTION}

Forensic anthropology is the sub-discipline of physical anthropology that implies the techniques of osteology and skeletal identification to problems of legal concern ${ }^{1}$. Stature is defined as the natural height in an upright position ${ }^{2}$. Stature of an individual is considered as one of the important parameter for personal identification and is an inherent character ${ }^{3}$. Long bones that makeup the greatest proportion of stature i.e. the femur, tibia and fibula are more accurate than humerus, radius and $u \mathrm{Ina}^{4}$. Due to the increased frequency of accidents, air plane crashes, mass disasters etc. this type of study is needed which helps in identifying the deceased from fragmentary and dismembered human remains $s^{5-10}$. Many authors around the world have successfully tried to estimate the stature from percutaneous body measurements. Many authors have corelated body height with length of femur, tibia, foot length and foot breadth ${ }^{11,12}$. Main contributor in height of an individual are the lower limb bones, hence the most predictive equations are based in the length of femur, tibia and fibula ${ }^{13}$. This study however focuses on tibia, as it resists erosion and keeps its anatomical shape for long time after burial. $22 \%$ of total body height is contributed by tibia alone ${ }^{14}$. The stature and length of bone of an individual is directly influenced by numerous factors like age, gender, race, geographical climate, nutrition and genetic factors. These factors give the idea that the co-relation for one given region is not ideal for another region ${ }^{3,15-20}$. So, it

1. Mr. Abhishek Poudel

2. Mr. Biswas Satyal

Address for correspondence:

Mr. Abhishek Poudel

Department of Anatomy

Nepalgunj Medical College Teaching Hospital

Chisapani, Banke, Nepal

Email: poudelabhishek@gmail.com becomes necessary to the researchers to have a study on a regional basis.

There are many ways of estimating body height from long bones, one of the accurate and easy way is by deriving the regression formulae for major long bones. However, this formula cannot be generalized to all population and hence it is necessary to derive equations in a particular population which can be applied for estimation of stature from skeletal remains ${ }^{17}$.

\section{MATERIAL AND METHODS}

A cross sectional study on 151 Nepali male students from Nepalgunj Medical College was done for the time period of one month of September 2017. Their age group ranging from 18-24 yrs. Parameters like age, gender, height in $\mathrm{cm}$ and percutaneous tibial length (PCTL) were noted. Students with history of major trauma or facture of leg were excluded.

For measurement of tibial length, individuals were asked to stand and keep his foot in a wooden stool. Angle between flexor surface of leg and that of thigh was maintained at $90^{\circ}$. Upper point at the upper border of medial condyle of tibia and lower point at the tip of medial malleolus was marked by skin marking pencil. Distance between two points was measured with the help of spreading caliper to determine length in $\mathrm{cm}$.

Height of an individual was measured in a standing position with both feet close contact with each other with trunk in upright position. The head was adjusted in Frankfurt plane. Measurements were taken in centimeters with the help of stadiometer.

\section{RESULTS}

The range of height was from $154.1-186 \mathrm{~cm}$ in present study and was divided in four quartiles. Maximum number of subjects i.e. 71 were with in the range of $171-180$ which is 
$47.02 \%$. The average height of subject was $169.76 \mathrm{~cm}$ with 7.02 standard deviation and 0.57 standard error.

\begin{tabular}{|c|c|c|c|}
\hline Sno & Range of Height & No. of Subjects & \% \\
\hline 1 & $151-160$ & 16 & 10.59 \\
\hline 2 & $161-170$ & 60 & 39.74 \\
\hline 3 & $171-180$ & 71 & 47.02 \\
\hline 4 & $181-190$ & 4 & 2.65 \\
\hline & Total & 151 & 100 \\
\hline
\end{tabular}

Table I: Showing distribution of number of subjects and their percentage according to height

Length of tibia was in the range of $26-45 \mathrm{~cm}$ in which the maximum number of tibia i.e. 99 were in the range of 36-40. The mean for right and left tibia were 36.881 and 36.883 respectively with standard deviation 2.052 in right tibia and 2.03 in left tibia. Standard error for both tibias were found to be 0.17 . Statistical analysis was not significant $(P>0.05)$ regarding the length of right and left tibia.

\begin{tabular}{|c|c|c|c|}
\hline Sno & Range of Tibia & Right Tibia & Left Tibia \\
\hline 1 & $26-30$ & 1 & 1 \\
\hline 2 & $31-35$ & 51 & 51 \\
\hline 3 & $36-40$ & 99 & 99 \\
\hline 4 & $41-45$ & 1 & 1 \\
\hline
\end{tabular}

Table II: Showing range of tibial length in accordance with the distribution of tibia

For estimating individual height, regression analysis was done by measuring tibial length. Linear correlation coefficient $(r)$ between height and the right tibia was 0.798 and to that of left tibia was 0.807 suggesting a positive co-relation between the length of tibia and estimated height.

After statistical analysis height can be estimated by using linear regression formula derived from the measured length of right and left side.

$\mathrm{y} 1=68.922+2.734 \times 1$

$y 2=68.951+2.787 \times 2$

y1 and y2 are estimated height right and left tibial length. $x 1$ and $x 2$ are the length of left and right tibia respectively. From the regression equation the mean stature was calculated from the right tibia as $169.61 \pm 5.59$ and from left tibia as $169.85 \pm 5.67$.

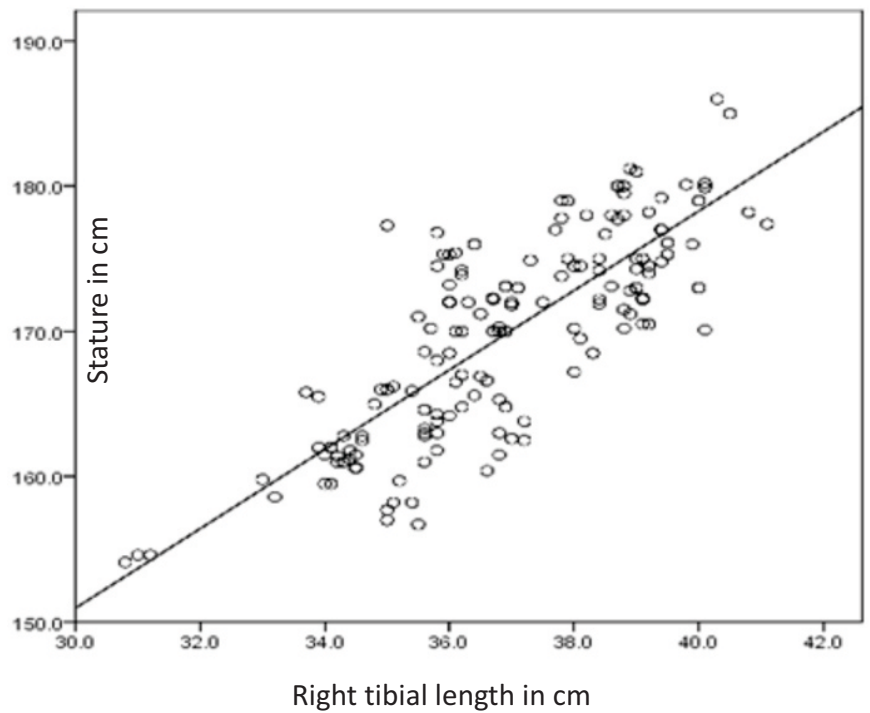

Figure 1: Showing correlation of stature and right tibial length

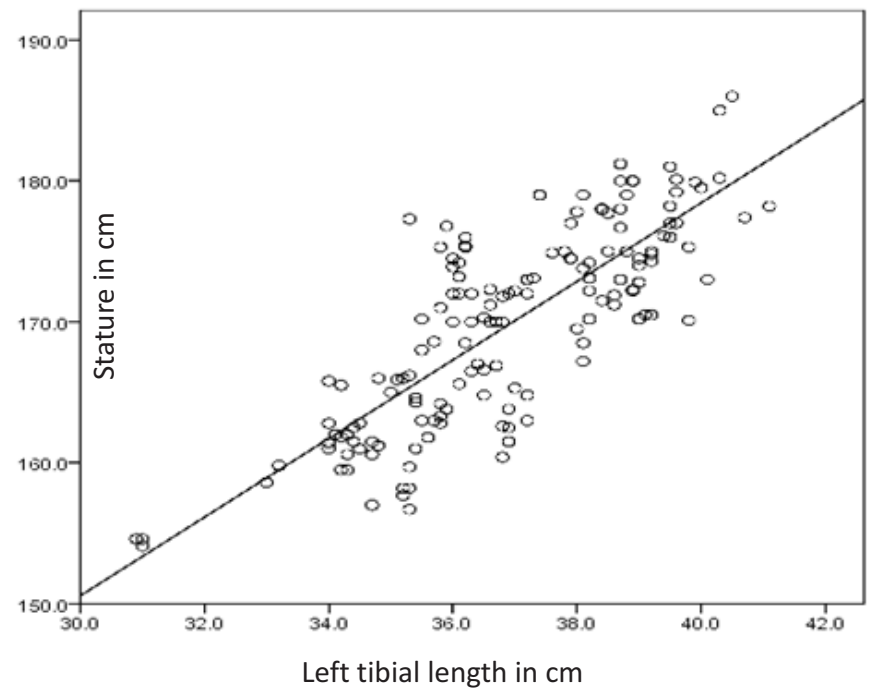

Figure 2: Showing correlation of stature and left tibial length

\begin{tabular}{|c|c|c|}
\hline Observations & Right & Left \\
\hline Independent variable $(x)$ & Length of tibia(x1) & 68.951 \\
\hline Intercept(a) & 68.922 & 2.787 \\
\hline Regression coefficient (b) & 2.734 & 0.807 \\
\hline Correlation coefficient ( $r)$ & 0.798 & 0.807 \\
\hline Coefficient of determination ( $\left.{ }^{2}\right)$ & 0.791 & $y 2=68.951+2.787 \times 2$ \\
\hline Regression formula: $y=a+b x$ & $y 1=68.922+2.734 \times 1$ & $169.85 \pm 5.67$ \\
\hline Mean \pm SD (Estimated Stature) & $169.61 \pm 5.59$ & \\
\hline
\end{tabular}

Table III: Formulation of regression equation for calculating the stature from the length of tibia 


\section{DISCUSSION}

Where bodies are found in highly decomposed and mutilated state or only skeletal remains are available the establishment of stature requires special attention. Earlier studies have established that the regression equations provide greater reliability in estimating stature ${ }^{18}$. Present study was carried out on living Nepalese male to correlate the percutaneous tibial length with body height in different stature groups. To estimate height a simple regression equation was derived.

In 1899 Karl Person, the first person to estimate stature through regression equation, estimated stature as $169.2 \mathrm{~cm}$ in male ${ }^{15}$. Pearson chose cadavers for calculation of stature and measured only the right-side tibia but our study focuses on the living population in Nepal and the measurements of both tibias. Study by Trivedi et al in 2014 in Gwalior region in India found that mean height of male to be $164.5 \mathrm{~cm}$, mean right PCTL $38.26 \mathrm{~cm}$ and mean left PCTL $38.22 \mathrm{~cm}$. The regression equation for right tibia was $y 1=110.76+14.04 \times 1$ and for left tibia was $y 2=103.71+1.59 \times 2^{21}$.

In 2014 study in northern India by Gupta et al have shown that the mean height of $168.56 \mathrm{~cm}$. The mean tibial length was shown as 37.23 and 37.33 for right and left side respectively. The regression formula derived was $y 1=80.03+2.37 \times 1$ for right side tibia and $y 2=79.26+2.39 \times 2$ for left side tibia ${ }^{22}$. Present study shows the mean height of $169.76 \mathrm{~cm}$, the mean tibial length for right and left side as 36.881 and 36.883 respectively. The derived regression equations as $y 1=68.922+2.734 \times 1$ for right tibia and y2 $=68.951+2.787 \times 2$ for left tibia. The stature of Delhi population by Mukta et al was established in $18-22$ years group. It was found that there is significant positive correlation of PCTL with body height in male. Estimated average stature was found to be $169.5 \mathrm{~cm}^{23}$. Kolte PM and Bansal PC in Marathwada region estimated average stature of $163.7 \mathrm{~cm}$ for male whereas Patil et al in Vidarbha region in Maharashtra India found that the average stature as $161.9 \mathrm{~cm}$ which shows the differences in height according to region ${ }^{24,25}$. Bhargava and Kher estimated mean stature of Barelas (tribe) as $161.5 \mathrm{~cm}$ and that of Bhills (tribe) as $160 \mathrm{~cm}$, in Madhya Pradesh India ${ }^{26}$. Bose in Eastern Bengal reported average stature for Bengalis as $166.6 \mathrm{~cm}^{27}$. Bhavna and Surendra Nath in their study on Shia Muslim male in India derived the linear regression equation as height in $\mathrm{cm}=84.74+2.27 \times(\mathrm{PCTL}) \pm 3.67^{3}$. Present findings are similar to that of Yayim Yilli, Agnihotri et al, Chaven et al, who observed that there are no statically significant differences in the length of right and left tibia in males $28,29,18$.

\section{CONCLUSION}

Percutaneous length of right and left tibia showed statically no significant in males, thus showing bilateral symmetry. The observed height and estimated height were in a close approximation within a range of error. It was thus concluded that there is a possibility of determining the stature of a deceased person whose only body part available is a mutilated leg, fairly accurately to some extent. However, the formulae derived cannot be generalized to all population groups, hence it is necessary to derive regression equations which are region wise and population specific.

\section{REFERENCES}

1. Ellis Kerley (1978) In: Warren MW, Walsh-Haney HA, Freas L E (2008) The Forensic Anthropology laboratory, CRC Press: Taylor \& Francis: London, New York 5-18.

2. Dorland's illustrated medical dictionary. $31^{\text {st }}$ ed. Philadelphia:Elsvier; 2007. Stature;p. 1793.

3. Bhavana, Nath S. Use of lower limb measurements in reconstructing stature among Shia Muslims. Internet J Biol Anthropol., 2009; 2(2): 86-97.

4. Lundy JK, Feldesman MR. Revised equations for estimating living stature from long bones of the South African Negro. S Afr J Sci 1987; 83: 54-55

5. Abdel-Malek AK, Ahmed AM, Sharkawi SAA. Prediction of stature from hand measurements. Forensic Sci Int 1990;46: 181-7.

6. Ozaslan A, Iscan MY, Ozaslan I. Estimation of stature from body parts. Forensic Sci Int 2003;132:40-5.

7. Kumar A, Srivastava AK, Verma AK. Estimation of Stature by Percutaneous Measurements of Distal Half of Upper Limb (Forearm \& Hand). J Indian Acad Forensic Med 2010;32:325-8.

8. Jain $\mathrm{P}, \mathrm{Kaur} S$, Nath $\mathrm{S}$. Reconstruction of stature from hand and foot dimensionsamong male Brahmins of Kumaon (India). J Ind Acad Forensic Sci 1996;35:22-9.

9. Sen J, Ghosh S. Estimation of stature from foot length and foot breadth among the Rajbansh: an indigenous population of North Bengal. Forensic Sci Int 2008;181:1-6.

10. Zeybek G, Ergur I, Demiroglu Z. Stature and gender estimation using foot measurements. Forensic Sci Int 2008;181:1-5.

11. Ozden H, Balci Y, Demirustu C. Stature and sex estimate using foot and shoe dimensions. Forensic Sci Int 2005;147:181-4.

12. Sigh JP, Meena MC, Rani Y. Stature Estimation from the Dimensions of Foot in females. Antrocom Online Journal of Anthropology 2013;9:237-41.

13. Brothwell D, Zakrzewski. Metric and non-metric studies of archaeological human bone. In: Brickley M, McKinley Jl, editors. Stature estimation. Guidelines to the Standards for recording Human Remains. Southamp-ton/Reading: BABAO/Institute of Field Archeologists; 2004.

14. Cox HWV. Medical jurisprudence and Toxicology. 6th ed. The law book company.1990;171-174.

15. Steele DG. Estimation of Stature from Fragments of Long limb bones, in: Stewart. T.D (ed.) Personal Identification in Mass Disasters. Smithsonian Institute: Washington D.C, 1970; 85-97.

16. Nath BS. Estimation of stature from long bones in Indians of United Provinces: A Medico-Legal enquiry in Anthropometry. Ind J Med Res 1931; 18: 1245-1253.

17. Kumar P, Shahnawaz K, Varma G. Study of Estimation of Stature by the Length of Femur. J Evol of Med Dent Sci 2014; 3(12): 316672. 
18. Chavan SK, Chavan KD, Mumbre SS, Makhani CS. Stature and Percutaneus Tibial Length: A Correlational Study in Maharashtrian Population. Ind J Foren Med Pathol 2009; 2(3):109-12.

19. Siddiqui MAH, Shah MA. Estimation of Stature from long bones of Punjabis. Ind J Med Res 1944;32:105-8.

20. Kaore A, Kaore BP, Kamdi A, Kaore S. Stature Estimation from Tibial Length. NJIRM 2012;3(2):51-6.

21. Tivedi A, Saxena S, Morya R. Stature estimation using percutaneous tibial length in people of Gwalior region. IOSR J Dent Med Sci 2014 May;13(5 Ver. 1):65-70.

22. Gupta P, Kumar P, Gahawar A. Correlation of percutaneous length of tibia with body height and estimation of stature in living north Indian males. Sch J App Med Sci 2014;2(2D):848-852.

23. Rani M, Tyagi AK, Verma SK., Kohli A; Estimation of stature from percutaneous measurements of legs. J Foren Med and Toxicol. 2004;21(1):12 -14.

24. Kolte PM, Bansal PC; Determination of regression formulae for reconstruction of stature from long bones of upper limbs in Maharashtra's of Marathwada region. J Anat Soc India 1974; 23:6 $-11$.

25. Patil TL, Gawhale RS, Muzumdar RD; Reconstruction of stature from long bone of both upper and lower limb. J Anat Soc India, 1983; 32(3):111-118.

26. Bhargava L, Kher GA; A comparative Anthropometric study of Bhils and Barelas of Central India. J Anat Soc India 1961; 10: 3133.

27. Bose A; Anthropometry of the Kayasthas of Bengal with special reference to Vangaj Kayasthas. J Anat Soc India, 1963; 12: 20- 25.

28. Yayim Yili. Estimation of stature from tibial length. J Foren Med 1996;12:87-93.

29. Agnihotri AK, Kachhwaha S, Jowaheer V, Singh AP. Estimating stature form percutaneous length of tibia and ulna in Indo Mauritian population. Foren Sci Internat 2009;87(1):109.el109.e3. 